\title{
The art of living: Vance Palmer and Eleanor Dark on the Sunshine Coast
}

\author{
Belinda McKay
}

b.mckay@griffith.edu.au

\begin{abstract}
Vance Palmer's The Passage (1930) and Eleanor Dark's Lantana Lane (1959) bracket the period during which the narrow coastal strip north of Brisbane from the Pumicestone Passage to the Noosa River was being transformed economically and culturally into what we know today as the Sunshine Coast. In the 1920s and 1950s respectively, Palmer and Dark participated in changing the region, and as established writers they reflected upon that metamorphosis in literary works that reached a national audience at a time when Brisbane's near north coast was off the beaten track for professional writers. But for millennia prior to colonisation, this area had sustained a vibrant economy and culture centred on bunyas from the mountains and seafood from the coast. By the late nineteenth century, this vast economic and cultural network had been radically disrupted by the incursions of timber-getters and pastoralists, and many of the traditional owners who had survived the frontier wars had been removed. While the inscription of a new identity on the region in the twentieth century was driven by the real estate speculators who coined the name 'Sunshine Coast', Palmer in The Passage and Dark in Lantana Lane share a more cooperative, sustainable, egalitarian and anti-imperialist vision for the region, with some indirect and ambiguous debts to its Aboriginal past.
\end{abstract}

\section{Introduction}

Vance Palmer's The Passage (1930) and Eleanor Dark's Lantana Lane (1959) neatly bracket the period during which the narrow coastal strip north of Brisbane from the Pumicestone Passage to the Noosa River was being transformed economically and culturally into what we know today as the Sunshine Coast, a name invented in 1958 by the real estate industry to promote tourism. ${ }^{1}$ In the 1920 s and 1950 s respectively, Palmer and Dark participated in changing the region, and as established writers they reflected upon that metamorphosis in literary works that reached a national audience. The Passage - which won The Bulletin prize in 1930 - chronicles the transformation of an isolated stretch of coast into a nascent regional centre, prefiguring both the surfing-based tourist economy on the coast and the cooperatives established by hinterland farmers during the inter-war period. Lantana Lane - the last published work of a novelist twice awarded the Australian Literature Society's gold medal - is set in a small-scale farming community on the Blackall 
Range; for many decades, this work has defied generic classification but from the vantage point of 2017 it seems to foreshadow the recent emergence of the blog as a new episodic literary form.

When Vance and Nettie Palmer lived in Caloundra from 1925 to 1929, and Eleanor and Eric Dark spent most winters and several summers near Montville in the 1950s, Brisbane's near north coast was off the beaten track for professional writers. But for millennia prior to colonisation, this area had sustained a vibrant economy and culture centred on the annual bonyi bonyis, or bunya festivals, on Dalla country at Baroon Pocket on the Blackall Range. As part of a cooperative regional economy, the saltwater peoples of the coast returned the hospitality when seafood was abundant. By the late nineteenth century, this vast economic and cultural network had been radically disrupted by the incursions of timber-getters and pastoralists, and many of the traditional owners who had survived the frontier wars had been removed to Barambah, Yarrabah or Palm Island. While the inscription of a new identity on the region in the twentieth century was spearheaded by the real estate speculators who coined the name 'Sunshine Coast', Palmer in The Passage and Dark in Lantana Lane share a more cooperative, sustainable, egalitarian and anti-imperialist vision for the region, with some indirect and ambiguous debts to the Aboriginal past.

\section{The Passage: Vance Palmer's 'white Aborigines'}

In White Aborigines: Identity Politics in Australian Art (1998) Ian McLean argues that the anti-imperialist Australian nationalism characteristic of the 1940s sought legitimacy in nativism and specifically in Aboriginalism: he points to Clem Christensen's appropriation of the Aboriginal name Meanjin in 1940 for a journal uninterested in Aboriginal culture as one of the first signs of this trend. In The Australian Legend (1958), Russel Ward draws on Frederick Jackson Turner's nativist ideology in the American context to articulate an Aboriginalism that, according to McLean (1998: 88), 'displaces Aboriginality within a white indigenity [sic]'. In The Passage, however, Vance Palmer was experimenting with 'white indigeneity'2 as a basis for nationalism at least a decade before the launch of Meanjin and nearly two decades before the publication of The Australian Legend. Nor was he the first writer to do so. Of particular interest in the South-East Queensland context is the Brisbane poet Cornelius Moynihan's long poem, The Feast of the Bunya (1901), about the bunya festivals held on Mobolon (Mt Mowbullan in the Bunya Mountains). Moynihan elides the frontier wars in his oddly cheerful conclusion that while the tribes have 'vanished' along with most of the bunyas, the 'pioneer residents' have assimilated the spirit of 'those easy-going later aboriginal inhabitants', and live in an 'ideal state' of harmony with their environment (Moynihan 1901: 23; see also McKay and Buckridge 2002: 72-6).

The Passage depicts the white Callaway family less as pioneers with alien origins than as natives who know the region aborigine, although that beginning is just one generation removed from the present, when Lew's father Bob and uncle Tony were born on an island in the Passage. Bob Callaway's 'fair, curling hair' and violin playing are the only characteristics that distinguish Palmer's sketch of him from contemporaneous literary portraits of Aboriginal men: he 'seemed as native to the place as the inconspicuous tea-tree or the mud-rooted mangroves. He knew every 
twist of the saltwater creeks, every channel where the incoming fish might pause to feed, every crab-hole in the banks, almost ...' (Palmer 1930: 23-4) And like the stock Aboriginal figure of white popular culture, he is inclined - in his own words - to go 'for a walkabout' (1930: 24) to the ranges at the height of the fishing season. Lew is more reliable than his father, and even more 'native to the place': 'The slanting sun streamed into his brown body. He was a gull skimming through the still air with spread wings; he was an anemone curled up waiting for the wash of the incoming tide; he was a carpet-shark drifting sluggishly along through the forests of water-weed' (1930: 16). In 1901, Cornelius Moynihan informed his readers that he had refrained from writing an epic about the bunya feasts on the grounds that only an Aboriginal bard who could 'think blackfellow' would be up to the task. Three decades later, Palmer deliberately tries to 'think blackfellow' as he envisions a white Australian identity based on a harmonious relationship with the environment.

Even the role of the white Callaways as purveyors of fish to the 'town' (Brisbane) mirrors the historical pattern. Ray Kerkhove (2013: 146), arguing that Aboriginal trade in fish and seafoods flourished in South-East Queensland between 1825 and 1880 , cites a piece entitled 'Turning the Tables' that appeared in the Moreton Bay Courier (17 August 1861: 2):

Until very recently the inhabitants of Brisbane depended mostly for a supply of fish upon the aborigines of this locality, very much, no doubt, to the profit, in a pecuniary sense, of these sable sons of the soil. Since, however, our enterprising townsman, Mr. Walker, has commenced hauling his seine in the waters of the Bay, the blackfellow has been almost driven from the field, and singular to relate, the blackfellow himself has become the purchaser from the white purveyor.

While some Aboriginal people continued to live on the sale of shellfish into the twentieth century, The Passage accurately depicts the domination of the fishing trade in the early twentieth century by white people like the Callaways, who closely resemble the well-known Tripcony family of Donnybrook on the Pumicestone Passage. ${ }^{3}$ Nettie Palmer's (1988: 18) observations in 1926 about Andrew Tripcony suggest that this family friend may have partly inspired Vance's portrait of Lew:

For most of his life [his brown legs have] been in the salt water, as he staked the oyster-beds that were his father's before him and, later on, turned to fishing, drawing his nets along the sandbanks. He never seems to feel any drive to get on or make much money. The mullet will come in every May, and there will be always a few visitors wanting to hire punts from him. He grew up on an inlet of the Passage, being one of a numerous brood who lived on whatever the seas sent them, keeping open house for the occasional stockmen, natives and fishermen wandering in. A quiet-voiced, humorous man, with the look of a kindly, experienced walrus.

Like the Tripconys, the Callaways gradually expand and diversify their humble fishing business in response to the growth of Lavinia (Caloundra). Lew, acting on the far-sighted advice of his uncle Tony, painstakingly accumulates enough capital to acquire a larger boat, take on employees and install refrigeration to transport produce to city markets.

Given Vance Palmer's close association with Aboriginal people, both in country towns in childhood and later on stations, most notably Abbieglassie in western Queensland in 1909-10, and his previous fictional and non-fictional writing 
about them, it is surprising that they are rendered virtually invisible in The Passage. ${ }^{4}$ The Caloundra area is within the traditional country of the saltwater Undumbi/Undanbi people, who are part of the Gubbi Gubbi language group, and in the novel Lew also visits the Blackall Range, traditionally Nalbo and Dalla land. The Palmers also knew at least one local Aboriginal man. In October 1928, Nettie Palmer (1988: 35) recorded that Dick Dalton 'fascinates' her: 'speaking, on the whole, a better English than anyone in the place'; he is 'a full-blooded aboriginal, with a clan of piccaninnies and collaterals tucked uncertainly into the scrub on the other side of the saltwater creek'. The only traces in The Passage of the region's traditional owners are a 'half-caste' who makes a cameo appearance, and the phantasmagoric delusions of a lost child.

Lew enters a 'long dive' competition as a show of virility, to attract the attention of the voluptuous but fickle Lena Christensen. An unnamed 'half-caste' dives further than any of the other white competitors, passing the mark of Lew's previous longest dive. Lew enters the water last, knowing that he must surpass himself, but his competitiveness dissipates when he enters his natural element:

Down in that world of greenish light he was at home, and he felt the current behind him, giving each stroke of leg and arm twice its proper value, sending him skimming like a startled fish a foot above the white sand.

He knew every inch of that sea-floor as well as the cropped green where he mended his nets. (Palmer 1930: 85)

When Lew finally emerges from the dive, he is surprised to find that he has gone even further than necessary to win; his nose is bleeding but, 'It was worth losing pints of blood to achieve that sense of rhythm and harmony' (Palmer 1930: 87). This episode is centrally important to the novel, as it demonstrates not only that Lew Callaway epitomises masculine vigour, but also that he has perfected the 'native' qualities of both his father and the 'half-caste'. Established from the opening scene of the novel as a being shaped physically and spiritually by place, Lew is a new kind of Australian: a white Aborigine.

Like his father and uncle, Lew knows and wants no other home, and apart from the love of European classical music that he inherits from his father, he is entirely shaped by the fluid and cyclical environment of the Passage. Taciturn and deliberate, he nonetheless has a 'strong, unconscious life': he 'absorbed [things] through that big, slow body of his, made them part of him'. Lew's particular kind of 'toughness' foreshadows the 'Australia of the spirit' that Vance Palmer evoked in his passionate plea in 'Battle' (1942) to Australians to 'make every yard of Australian earth a battle-station':

Born of the lean loins of the country itself, of the dreams of men who came here to form a new society, of hard conflicts in many fields, it has developed a toughness all its own. Sardonic, idealist, tongue-tied perhaps, it is the Australia of all who truly belong here ... And it has something to contribute to the world. Not emphatically in the arts as yet, but in arenas of action, and in ideas for the creation of that egalitarian democracy that will have to be the basis of all civilised societies in the future. (Palmer 1942: 5)

As a result of the 'old-world imperialism' where the land 'has been something to exploit, to tear out a living from and then sell at a profit', Palmer fears that 'we 
could vanish and leave singularly few signs that, for some generations, there had lived a people who had made a homeland of this Australian Earth'. Although he wrote these words in fear of imminent Japanese invasion, Palmer had long been creating avatars — including Hamilton in The Man Hamilton (1928) and perhaps most powerfully Lew in The Passage - whose function was to reveal how Australia could indeed be a 'homeland' for white Australians.

Whether or not Palmer was familiar with it, the Callaway clan and Lew as its finest nativist product exemplify Turner's American frontier thesis:

The wilderness masters the colonist ... [A]t the frontier the environment is at first too strong for the man. He must accept the conditions which it furnishes or perish... Little by little he transforms the wilderness, but the outcome is not the old Europe ... The fact is, that here is a new product that is American. (Turner 1893: 201)

Or, indeed, 'Australian'. While Lew is unequivocally a new product, fully adapted to the new land, the Passage is certainly 'too strong' an environment for some whites, including members of the Callaway clan. Lew's older siblings and cousins have drifted away from the Passage in search of easier ways of earning a living in the city. His younger brother, Hughie, is unsuited to the life of a fisherman: his fair skin burns without tanning, and he has to be rescued by Lew when his grandiose capitalist schemes leave him bankrupt and alcoholised in the city. Lew's son Peter — the offspring of an unsuitable marriage with Lena — is feeble in mind and body, and perishes in the Australian bush.

In his portrait of this doomed child, Palmer modernises the nineteenth-century trope of the child lost in the bush with more than a hint of eugenic theory. Resentful of her unwanted pregnancy, Lena defies Lew's warning against swimming in a dangerous stretch of sea and nearly drowns. When Peter is born at only seven months' gestation, his survival initially hangs in the balance and he grows up afraid of everything: 'he seemed to carry in his mind some image of a violent and monstrous world that was intent on crushing his feeble little body' (Palmer 1930: 165-6). Lena by turns teases the boy and smothers him with caresses, in which Lew detects 'an unpleasant hint of flirtation' (1930: 166). Attempting to provide a counterbalancing masculinity, Lew takes Peter out beyond the bar in the dinghy, but the boy is mesmerised with 'horror' when he sees killer whales hunting a larger whale: imagining a killer attacking the dinghy, he bravely stabs at it but overcome by 'sudden awe', he loses an oar. It takes all of Lew's experience and strength to bring the dinghy home safely in adverse weather conditions. Despite this experience and Peter's resultant 'shivering fit' — presumably an epileptic seizure Lew remains convinced that Peter was just 'a bit nervy, and had more imagination than most youngsters. All he needed was a bit of toughening' (1930: 203, 207).

When Peter wanders off alone in search of the famed scarlet and gold Christmas bells in the nearby pademelon country, his fate is sealed. In the moment of cutting the trophy flowers, he suddenly senses with horror the lurking presence of

blacks painted for a corroboree, their spears standing up in serried ranks, their dark eyes staring through rings of white! Rigid and terrible they stood, making no sound, merely watching him with a fixed look that was awful in its intensity.' (1930: 234) 
Running terrified through the bush, he reasons with himself that he has seen 'a bunch of grass-trees, blackened by fire' because 'There weren't any more blacks; they had all died years ago ... It was only in pictures you saw them like that, with feathery things on their heads and white paint round the eyes. Pictures couldn't come alive!' (1930: 234-5). A close encounter with a red-bellied black snake again strikes terror into him, and the narrator leaves the terrified Peter staggering through the bush, parting the tall grass with his arms, desperately attempting to find the track that will lead him home. His body is found the following day in a 'pothole of water' by a search party. A grief-stricken Lew eschews a grave in the cemetery at Lavinia, and rows out beyond the reef to consign his son's body to the sea.

In this depiction of Peter, Vance Palmer may have evoked a deep-seated racial fear that in his view had to perish if the new country were to become a 'homeland'. In an article on Palmer's formative years in Queensland, Deborah Jordan (2008: 203) cites a letter written by Vance to Nettie in which he recalls lying awake at night as a child, paralysed 'by a sort of dream terror' during which he imagined 'the eyes that came peering in through the window from the dark outside'. The image resembles the dreams of being 'on an outstation besieged by Blacks' that haunted Rosa Praed (1885: 27) throughout her life, but that at the same time drove her creativity (McKay 2016). Jordan (2008) argues that Palmer's work as a tutor and bookkeeper on Abbieglassie Station in western Queensland in 1909-10, which brought him into close contact with the Kooma people, 'may have appeased earlier racial fears'. Palmer drew overtly on the Abbieglassie experience in his novels Cronulla: A Story of Station Life (1924) and The Man Hamilton (1928). In The Passage, however, the depiction of Aboriginals as a dead race works to displace Aboriginality and disguise the extent of Palmer's reappropriation of it in his depiction of Lew as an exemplary white Australian.

In the final pages of the novel, Lew steps up to the responsibility of leadership within his small community, and on the symbolic level becomes a model for how white Australians can create a homeland instead of a short-term resource to exploit, destroy and abandon. As a white Aborigine - a man who belongs to country Lew is uniquely placed to develop a sustainable, cooperative and egalitarian regional economy in contrast to capitalist speculation and rapine that shows no commitment to country or community. In The Passage, the real estate speculators abandon Lavinia, 'an artificial growth, a place that depended on a flow of life from the outside' and Lew welcomes a renewal and expansion of the sustainable economy of the Passage: 'There would always be the shoals of mullet coming in from the sea and an increasing flood of butter and fruit from the country around: it would develop naturally like a plant with its roots in good soil' (1930: 276). Lew's vision at the end of the novel is a re-creation of the network of cooperation between coast and range that had existed on a vast scale less than a century before: 'The orange-season had begun, and big loads were coming down from the range; besides a new buttery-factory had started, and was giving him all its carrying. Never had there been such a continuous bustle at the jetty ...' (1930: 192) With the advantage of hindsight, the twentieth-first-century reader knows that the 'artificial growth' of Lavinia will soon begin again, and the Passage's days as a bustling port are numbered. However, the novel captures the tension between sustainability and exploitation that is an enduring feature of the identity of the Sunshine Coast. 


\section{Lantana Lane: Eleanor Dark's agri/cultural experiment on the Blackall Range}

Thirty years later, the narrator of Lantana Lane (1959) looks down from a ridge on the Blackall Range, reversing Lew's perspective but nonetheless sharing the interconnectedness symbolised for him by 'the threads of road running up the sides' of the mountains:

Miles of farmlands lie below, lightly linked by ribbons of red road to the clustered roofs of little towns, and beyond them blue ocean and white beaches proclaim a stretch of the long, Queensland coastline, fading north and south into a haze of distance. (Palmer 1930: 16)

Just as Caloundra had provided the Palmers with what Nettie described as 'time to read and think', and a sense that 'The place has become part of us' (Palmer 1988: 40-1), so the Blackall Range became for Eleanor Dark a vantage point from which to reflect on ways of living.

Eleanor and Eric Dark arrived in Montville in early 1951, and over the summer of 1951-52 Eleanor completed No Barrier (1953) the final novel in the Timeless Land trilogy, which she had begun writing (after some years of research and planning) in 1937. Although Dark had been at pains to point out in the preface to the first novel in the series that 'I make no claim to strict historical accuracy either in my dealings with the white men or the black' (Dark 1941: 7), Tom Griffiths (2016) has recently claimed Dark as an historian, devoting the first chapter of The Art of Time Travel: Historians and Their Craft to her on the grounds that she was 'decades ahead of Australia's historians in realising that the big story about British colonisation at Port Jackson was that of the encounter between settlers and Aborigines' (Griffiths 2016: 26). In the trilogy, Dark deliberately attempts to 'think blackfellow', as Moynihan (1901) puts it, not only because the work is centrally concerned with the different points of view of blacks and whites but also because 'the race is nearly gone' and with it will go 'something which the "civilized" world has scorned too easily': an 'art of living' developed to a very high degree. In Lantana Lane, Dark explores how white Australians in the Cold War era might focus less on the technique and more on the art of living - with the unstated underlying premise, as in The Passage, that Aboriginal people and their culture are gone.

Although the Darks' home in Mill Hill Road - named 'Bopplenut' ${ }^{5}$ after the Aboriginal word for the macadamia nut — was situated directly above Baroon Pocket where the bunya festivals of the Dalla people had taken place for millennia, Lantana Lane is silent about this history. Dark must have been aware of the Aboriginal history of the area, but Nelson, the highly adaptable kookaburra, is one of the few hints of a world that existed before the clearing of the land where two exotic species - lantana and pineapple - now vie for supremacy. Dark moved to Queensland at the age of 50, disillusioned with the prospects of a New World Order based on peace and justice, and apprehensive about impending nuclear warfare. She and Eric were seeking respite from the political persecution that their socialist leanings had attracted in the Blue Mountains, and also wanted to be close to their son Michael and friend Eric Lowe. In Montville, at least for a few years, Eleanor explored new ways of effecting fundamental social change, in some respects anticipating the 'slow' and sustainability movements of the late twentieth 
century. For a while it seemed to her that political activity mattered less than shared communal enterprises and simply finding ways of enabling people to get along with each other at the micro-level of an economy based on labour rather than capital.

Like Vance Palmer, Eleanor Dark had long experimented with the idea that white Australians needed to learn from Aboriginal people. In the Blue Mountains, the Darks' passion for bushwalking was driven in part by their desire to appreciate the Aboriginal connection with the land. During the writing of The Timeless Land, Eleanor, Eric and the children, John and Mike, regularly camped in a cave that they named Jerrikellimi, a made-up word that was in fact a composite of their names but had an Aboriginal ring to white people. By 1944 she was referring explicitly to the theft of the land from Aboriginal people and linking it to unsustainable exploitation of the land. Against the achievements of white Australia, she wrote,

must be set the ignorance and greed that used the land too recklessly, overstocking it till pastures became deserts; denuding the earth ... felling trees irresponsibly; building barbarously with no thought of beauty. And, darkest of all blunders, heaviest upon our conscience, the blunder of our dealings with black Australians whose land we stole. (Dark 1944: 10-11)

Dark's admiration for the Aboriginal art of living also led her to speculate in 'The Conquest of Nature' (Dark n.d.) that the move to agriculture elsewhere in the world had been a 'false step towards dominating nature'. Lantana Lane can be seen as her attempt to think through ways of mitigating the effects of that irreversible step, which Dark archly refers to in Biblical terms as 'the Curse' that has pursued humans for 6000 years. Adam was a 'caretaker', but Eve's desire for knowledge turned humans into farmers. God rejects the offering of her farmer son Cain, who kills his preferred brother, the shepherd Abel. Although the farmers who inhabit the Lane have the mark of Cain upon them, ironically in an age of expanding capitalism and the threat of nuclear war it is these 'Anachronisms' who have

a vague notion that in order to become civilised, one must, first of all, remain human. And being human, we feel, has at least something to do with treading on earth, getting sweaty, seeing the sun rise, making things grow, having animals around, using one's muscles, taking one's time, getting on with one's neighbours and feeling no need of tranquillising pills. Nor have we failed to note that the faster we move, and the more conveniences we acquire, the less of our brief, precious and irreplaceable time we have to call our own. (Dark 1959: 252)

In other words, these idiosyncratic, small-scale farmers point to ways in which the modern world can re-learn how to place the art above the technique of living.

Whatever Dark originally expected or intended from her time in Queensland, the 'Bopplenut' experience was fruitful on several levels. Marivic Wyndham's (2007) categorisation of the Darks in Montville as 'hobby farmers' is not quite fair or accurate. Although they didn't depend on the income from their farm, and usually spent only winters in Montville, Dark was nonetheless engaged in a serious agri/cultural enterprise that anticipates a permacultural model of doing just enough physical labour for a garden to thrive, working with rather than against nature and leaving time for other activities. Dark's depiction of Lantana Lane resident Bruce Kennedy - a character based on her husband Eric, who was influenced by the work of Lady Evelyn Balfour (Brooks and Clark 1998: 392) — could readily apply 
to any number of contemporary hinterland farmers dedicated to sustainable and organic agricultural practices:

He belongs to the compost and organic manure school of thought, views chemical fertilisers with reserve, and will talk for hours about methods of controlling erosion, the need for preserving soil-bacteria, and the evils of monoculture. He is enthusiastic about worm-casts ... on Bruce's farm not even Royalty could be more warmly and respectfully welcomed. (Dark 1959: 16)

Dark also foreshadows contemporary concerns about climate change in her prediction that our attempts to outwit Nature will be the cause of our own destruction:

Possibly we should do well not to rile this ancient lady [Nature]. Possibly Hell hath no fury such as that which is even now consuming her, and if so, we had better beware, for she still has a few trumps in her hand. She can still insist, for example, that we must breathe, and though much of the spray which has freed us from chipping does undoubtedly descend on the weeds, and knock them cold, it may be that a residue rises to sport with the playful wind, which perhaps is already sporting with the residue of all the other sprays, and all the other by-products of our scientific genius, including atomic fall-out. (Dark 1959: 95-6)

Not even the isolated rural community of Lantana Lane can escape the forces of mechanisation, 'development', the globalisation of capitalism and the threat of nuclear war. The dangers to the Lane are conflated into 'The Deviation', a plan by the Department of Main Roads to connect the regional centres of Dillillibill and Tooloola by a straight road along the shortest route, which happens to be the Lantana Lane ridge. 'The Deviation' will transform the Lane from a dead end into a 'through road', sweeping its inhabitants into modern capitalist processes (Dark 1959: 40).

Dark's agri/cultural experiment also manifests itself in the stylistic hybridity, archness of tone and episodic structure of Lantana Lane, which resembles forms of contemporary writing such as blogs more than a traditional novel or story collection. Indeed, some of Dark's essays, such as 'The Blackall Range country' in Walkabout (Dark 1955) are similar in tone and subject matter to chapters in this 'novel'. One of the most seductive aspects of Lantana Lane is the playful way in which Dark conflates physical and intellectual labour. Today, rather than being sui generis, Dark's transformation of the hinterland into a vantage point from which to reflect on modes of production is a harbinger of twenty-first century creative non-fiction. Contemporary Blackall Range permaculture practitioner and writer Nina Gartrell's 'A Writer's Day' (2016) is worth quoting at length because its striking affinities with Lantana Lane illuminate how extraordinarily current the older work remains:

Start work.

Three to four hours of generating 'fresh' words. I call this process 'seeding'. It's how I flesh out the narrative and get words down on paper.

Break.

Usually about 1 hour, during which I undertake a combination of the following: wash dishes (whilst listening to Margaret Throsby's midday interview); make bed; browse the garden; eat lunch; prepare the evening meal. 
Afterwards I resume work for another 2-3 hours. Time to edit the 'old' work I produced last week during my 'seeding' sprees. I call this part 'weeding', though sometimes it's more like turning over the compost, trying to make the various elements disperse and break down more evenly. Integrate. Obtain a fine tilth. A perfect growing medium.

The final hour is of gentler, less intensive work. Sometimes it's note-taking from secondary texts I'm working with: travel memoirs; natural histories; permaculture handbooks; or ethnographies ... This is the most brain-dead part of the day, reserved for things like notetaking or backing-up.

Eventually, it's time to finish. How to break the intensity of the day?

I try to leave the studio neat and tidy for tomorrow. Coming into an orderly space helps. I neaten the piles of books, pages, pens, drafts and drafts of drafts. They're piling up. Soon I'll have to confront them and file them away. When the doctorate is over I'll probably mulch the garden with the seeding pages. I'll be eating my words!

On her farm on the Blackall Range, Dark too found that 'the small-scale production of sustenance - whether mental, physical or spiritual' - aided 'subversive' thinking in unexpected ways that generated a work that in its time, and in the context of her previous work, was sui generis (see McKay 2001).

Although 'Lantana Lane' was never, except in the loosest sense, an intentional community like William Lane's New Australia experiment in Paraguay or Dark's fictional Hy-Brazil in Prelude to Christopher, it is, as Brooks and Clark (1998: 404) observe, a 'moral community'. The narrator suggests that challenges of smallscale farming spontaneously generate not only subversive thinking but an ethic of cooperation, sustainability and egalitarianism. A daily routine of work limits the capacity of the Lane's inhabitants to 'expand' into grandiose or political schemes. And the virtual impossibility of producing surpluses inhibits expansion based on the accumulation of capital. Like Voltaire in Candide, Dark toys here with the notion that simply 'cultivating one's garden' might make the world a better place; like Voltaire, Dark was writing with a conviction born of experience: her semi-exile in the garden at 'Bopplenut' was not altogether dissimilar to his rather more luxurious exile with two master gardeners at Les Délices in Geneva (Davidson 2004). In the end, of course, the real-life utopian experiment behind the fiction collapsed as much from internal as external factors. Eric Lowe was forced to sell his farm, and, after the Darks moved back to Varuna, Ann - the dedicatee of Lantana Lane - left Eleanor and Eric's son Mike for John, Eric's son from his first marriage. But Eleanor Dark's final work remains in print - and even available for digital download — unlike Vance Palmer's The Passage.

\section{Conclusion}

In the era between the destruction of the Aboriginal culture and economy centred on the bunya festivals of the late nineteenth century and the emergence of the 'Sunshine Coast' as a major tourist destination in the 1960s, Vance Palmer and Eleanor Dark were inspired by this liminal space to speculate on how white Australians might develop a more egalitarian, cooperative and sustainable way 
of life than they had in parts of the country that had been colonised earlier and more densely. Both The Passage and Lantana Lane are virtually silent on the Aboriginal past and present of the region, but in reinscribing it with a new identity, Palmer and Dark draw on their understandings of Aboriginal culture as better adapted to the land and human relationships. In The Passage, Palmer depicts his main character Lew Callaway as a 'white Aborigine', a new product of the Australian environment who perfects the old (black) way of life and takes it into the (white) future. In Lantana Lane, Dark considers how white people can regain something of the 'art of living' that she believed Aboriginal people had developed to a high degree.

Since the 1980s, the Sunshine Coast and its hinterland have attracted many successful writers, including Peter Carey, David Williamson, Peter Corris, James Cowan and Bruce Dawe. However, it is a curious fact that very few of those who live or holiday in the region have actually used this location in any significant way in their work. For the true heirs of Palmer and Dark, perhaps we need to look beyond the famous names to emerging writers like Nina Gartrell for parallels with Dark's project of intertwining meticulous observation of local life, in which she participated as a farmer, with wider cultural and political concerns.

\section{Endnotes}

1 The campaign for the new name was launched by the Real Estate Institute of Queensland at the Hotel Caloundra in December 1958, and the change of nomenclature was endorsed under the Queensland Place Names Act 1958 on 1 August 1967. In November 1966, the Landsborough, Maroochy and Noosa Shire Councils agreed to adopt the name 'Sunshine Coast' while retaining their status as independent local government areas until 2008, when an amalgamated Sunshine Coast Region was established. In 2013, Noosa residents voted to de-amalgamate and the Shire of Noosa was re-established from 2014 - a development that ended Noosa's official association with the Sunshine Coast. In 2017, the Sunshine Coast Council is running a series of 50th Anniversary celebrations of the official naming of the Sunshine Coast.

2 Throughout his 1998 book, McLean uses the less common form of the abstract noun: 'indigenity'. I have chosen to adopt the now standard form 'indigeneity'.

3 To achieve a closer juxtaposition of contrasting lifestyles than between Donnybrook and Caloundra (nearly 50 kilometres apart), Palmer locates the fishing village within a mile of the fictional Lavinia (Caloundra), roughly corresponding to the position of Golden Beach.

4 One of Vance Palmer's earliest publications, 'The Australian Corroboree' (1906), demonstrates an interest in Aboriginal culture, but apart from a brief reference to his childhood contact with Aboriginal people, the article summarises material by Tom Petrie and W.E. Roth.

5 Macadamia integrifolia, like the bunya, is native to the Blackall Range. Known colloquially as the bopple or bauple nut, bush nut, Queensland nut or Gympie nut, the macadamia is native to the area but threatened in the wild (Barry and Thomas 1994). One of the Darks' first activities on moving to Montville was to pack boxes of macadamia nuts. Their 1926 Queenslander house, 'Bopplenut', at 41 Mill Hill Road has recently been lavishly renovated, and is surrounded by 13 acres [5.2 hectares] of rainforest and 7 acres [2.8 hectares] of landscaped tropical gardens. It has been renamed 'Montville Macadamery' in reference to past use of the site by the University of Queensland for research into genetic improvement of the macadamia species. 


\section{List of works cited}

Barry S.J. and Thomas G.T. 1994. Threatened vascular rainforest plants of South-East Queensland: A conservation review. Canberra: Queensland Department of Environment and Heritage/ANCA.

Brooks Barbara and Clark Judith 1998. Eleanor Dark: A writer's life. Sydney: Macmillan.

Dark Eleanor 1941. The timeless land. Sydney: Collins.

_ 1944. 'Australia and the Australians'. Australian Weekend Book 3: 9-19.

— 1953. No barrier. Sydney: Collins.

— 1955. 'The Blackall Range country', Walkabout, 1 November: 20.

- 1959. Lantana Lane. London: Collins.

— n.d. 'The conquest of nature'. Typescript, Eleanor Dark Papers, Mitchell Library, Sydney, MLMSS 4545, Box 10.

Davidson Ian 2004. Voltaire in exile: The last years 1753-78. London: Atlantic.

Gartrell Nina 2016. 'A writer's day'. Permaculture Traveller, 13 April, https://typotraveller.wordpress.com.

Griffiths Tom 2016. The art of time travel: Historians and their craft. Melbourne: Black Inc.

Jordan Deborah 2008. 'The making of the Australian legend: Vance Palmer in Queensland 1885 to 1910', Royal Historical Society of Queensland Journal 20.6: 195-216.

Kerkhove Ray 2013. 'Aboriginal trade in fish and seafoods to settlers in nineteenthcentury South-East Queensland: a vibrant industry?', Queensland Review 20.2: 14456.

McLean Ian 1998. White Aborigines: Identity politics in Australian art. Melbourne: Cambridge University Press.

McKay Belinda 2001. 'Writing from the hinterland: Eleanor Dark's Queensland years', Queensland Review 8.2: 21-8.

McKay Belinda 2016. 'Proleptic modernism? A reconsideration of the literature of colonial Queensland', Queensland Review 23.2: 116-32.

McKay Belinda and Buckridge Patrick 2002. 'Literary imaginings of the bunya', Queensland Review 9.2: 65-79.

Moynihan Cornelius 1901. The feast of the bunya: An Aboriginal ballad. Brisbane: Gordon \& Gotch.

Palmer Nettie 1988 [1926].Nettie Palmer: Her private journal Fourteen years, poems, reviews and literary essays. Ed. Vivian Smith. St Lucia: University of Queensland Press.

Palmer Vance 1906. 'The Australian corroboree', The Nineteenth Century and After 60 (August): 315-20.

- 1924. Cronulla: A story of station life. Sydney: Cornstalk.

— 1928. The man Hamilton. Melbourne: Ward, Lock.

- 1930. The Passage. London: S. Paul.

- 1942. 'Battle', Meanjin Papers 1.8: 5-6.

Praed Rosa 1885. Australian life: Black and white. London: Chapman \& Hall. 
Turner Frederick J. 1893. 'The significance of the frontier in American history'. In Annual Report of the American Historical Association for the Year 1893, pp. 199227.

Ward Russel 1958. The Australian legend. Melbourne: Oxford University Press.

Wyndham Marivic 2007. 'A world-proof life': Eleanor Dark, a writer in her times, 1901-1985. Sydney: UTS ePress. 